\title{
Catenary Variation of Soil Properties under Oil Palm Plantation in South Western Nigeria ${ }^{*}$ Aweto A.O. and ${ }^{* *}$ Enaruvbe G. 0
}

\begin{abstract}
This study characterizes variations in soil properties in a catena under a 30-year oil palm (Elaeis guineesis) plantation established on sedimentary soil in south-western Nigeria. A 300 metre transect was delimited in an oil palm plantation adjoining a tributary of Ossiomo River at Okhuo, near Benin, Nigeria. The transect was divided into upper, middle and lower slope segments. Each segment was further subdivided into ten 10 by 10 metres quadrats, making a total of 30 quadrats. Five soil samples were randomly collected from $0-20 \mathrm{~cm}$ layer of each quadrat and analysed for particle size composition, organic carbon, macronutrients and micronutrients.

Exchangeable calcium and cation exchange capacity were significantly higher in the middle slope segment of the catena due to the combined influence of soil organic matter and clay which were also higher in the middle slope than in the upper and lower slopes. Soil pH was highest in the upper slope and declined down slope. There were no significant variations in the levels of extractable manganese, copper and zinc between the upper, middle and lower slopes but extractable iron was significantly higher in the lower slope due to the occurrence of more moist and acidic soils in the lower slope. Topographic position and ground slope are the main factors accounting for variations in soil properties along the catena. There is the need to manage parts of oil palm plantation on different topographic positions differently, taking cognizance of variations in soil properties along the catena, in order to ensure long term sustainability.
\end{abstract}

Key words: Oil palm, catena, soil, macronutrients, micronutrients, Nigeria.

\section{Introduction}

$A_{\text {plantation agriculture, featuring }}^{\text {s with other parts of the tropics, }}$ the production of crops in monocultures in large commercial estates, has gained widespread acceptance and has consequently, become an important feature of the agricultural economy of tropical Africa. The plantation system of agriculture is assuming increasing popularity, particularly in tropical countries such as Malaysia, Indonesia, Cote d'Ivoire, Nigeria and many other parts of the world. Evans (1992) reported that the areal extent of plantation agriculture of all types doubled in tropical Africa and increased about six fold in other parts of the tropics between 1965 and 1980.

This increasing interest in plantations can be attributed to advantages of the plantation system of agriculture, such as environmental conservation and protection, and economic and social benefits. Tree crops are commonly grown in plantations in the tropics. Some of these include coffee (Coffea arabica), cocoa (Theobroma cacao), rubber (Hevea braziliensis) oil palm (Elaeis guineensis), eucalypts (Eucalyptus spp), teak (Tectona grandis), gmelina (Gmelina arborea) and pines (Pinus spp.). Small-scale indigenous farmers in West Africa have embraced monoculture, a diagnostic feature of plantation agriculture, and a significant proportion of exports such as cocoa, coffee, rubber and palm oil and kernel of the subregion comes from peasant holdings.

Most of tree crops such as teak, gmelina, pines, eucalyptus, cocoa and para rubber grown in plantations in West Africa are exotics. The oil palm (Elaeis guineensis), a native of tropical West Africa occurring in a zone extending from Guinea to Congo basin (Irvine1969, Onwueme \& Sinha 1991) is a noteworthy exception. Nigeria was the world's largest exporter of palm oil and kernel in the 1960s accounting for $43 \%$ of the world's production. Today, however, it only accounts for $7 \%$ of total output (World Rainforest Movement 2001). The country has ceased to export palm oil and is now a net importer of vegetable oil. Most of the oil palm plantations and the small-scale peasant holdings in Nigeria were established without adequate consideration of the impact of environmental factors, especially, the soil and its spatial (and hence, catenary) variation on the productivity and sustainability of oil palm plantations. The soil varies along the landscape, even within limited areas, giving rise to a succession of soil types, known as a catena, from the hill top to the valley bottom (Milne 1935). The catenary differentiation of soils is of pivotal importance to the management of soils in different topographic positions in the landscape, especially in large plantation monocultures. 
Several studies have examined the ecological requirements and environmental impact of oil palm on soil ( Irvine 1969, Onwueme \& Sinha 1991, Aweto \& Ekiugbo 1994), while others considered catenary relationship between slope, soil and vegetation in the tropical environment (Furley \& Newey 1979, Aweto \& Iyamah 1993, Abrams et al 1997). Apart from Vine (1941) who studied a catena under cacao in south western Nigeria, it appears that catenas under tree crop plantations have not been characterized and hence, soil variation along topography in these plantations have not been adequately studied. This study therefore attempts to evaluate catenary variation of surface soil properties under oil palm (Elaeis guineensis) in South Western Nigeria. Studies on catenary differentiation of soils in the forest zone of Nigeria concentrated on soil profile characteristics and macronutrients and ignored micronutrients (Vine 1941, Smyth \& Montgomery 1962, Ogunwale et al 1986, Aweto \& Iyamah 1993) which sometimes exert a more severe limiting effect on the growth of crops, tree and field crops inclusive. It was therefore considered important in the current study to evaluate the extractable micronutrients iron, copper, lead and zinc in different slope segments in a catena under oil palm, in addition to the macronutrients routinely analysed in pedological studies.

\section{Study area}

The present study was conducted at Okhuo, about 25 kilometres to the north east of Benin City, the capital of Edo State, Nigeria. The area is a part of the coastal plain of southern Nigeria and is generally below 120 metres above mean sea level (Udo 1970). The topography is gently undulating, except near rivers where steep slopes occasionally occur near the floors of the river channels. The climate is tropical rainforest climate (Koppen's Af climate) with a bi-modal rainfall regime. The mean annual rainfall is about $1700 \mathrm{~mm}$, with most of the rains concentrated in the wet season lasting from March to October. Two periods of peak rainfall occur in June - July and September - October, the two peaks being separated by a relatively dry period in August. Temperatures are relatively uniform throughout out the year, with an average annual average of $27^{\circ} \mathrm{C}$ and no marked seasonal or monthly departure from the annual average (Figure 1)
The natural vegetation is moist evergreen rain forest ( Hopkins 1974) that is rich in timber producing trees such as Piptadeniastrum africanum, Triplochiton scleroxylon, Milicia excelsa, Antiaris toxicaria and Ceiba pentandra. Raffia palms, especially Raphia hookeri and Raphia vinifera are locally abundant in riparian forests fringing rivers. As a result of centuries of traditional agriculture featuring rotational bush fallowing and the production of cassava (Manihot esculenta) and maize (Zea mays) coupled with unsustainable timber exploitation, the natural forest vegetation has been destroyed. The soils are sandy and were derived from sedimentary rocks, especially unconsolidated sediments of sandstone of Tertiary Age. They are mainly Ultisols, according to United States Soil Taxonomy ( Soil Survey Staff, 1996) and Acrisols according the Food and Agricultural Organization system of soil classification. The soils are deeply weathered, strongly leached and lack significant weatherable minerals within the soil solum.

\section{Methodology}

In this study, a sloping portion of a 30 - year old oil palm plantation, adjoining a tributary of the Ossiomo River, was selected for the purpose of evaluating the impact of topography on soil physical and chemical properties in a plantation of the same age. Differentiation of soils along a catena is most marked along transects running from the crest of the interfluve to the valley bottom ( Gerrard 1981). Accordingly, a transect was delimited on the valley slope of the tributary of the Ossiomo River, traversing the plantation, from the crest of the spur to the valley bottom. The transect was 300 metres long and it was divided into three slope segments - the upper, middle and lower slopes. Each of the three slope segments was further sub-divided into ten quadrats measuring 10 metres by 20 metres, making a total of 30 plots. At the centre of each quadrat, slope angle was measured using an abney level. Soil samples were collected from five randomly selected points within each plot at the depth of $0-20 \mathrm{~cm}$ using a soil auger. The five samples for each quadrat were mixed thoroughly together to obtain a composite sample. Soil sampling was restricted to the top $20 \mathrm{~cm}$ of the profiles because it is the most productive soil layer that exerts the greatest effect on crop yield. 


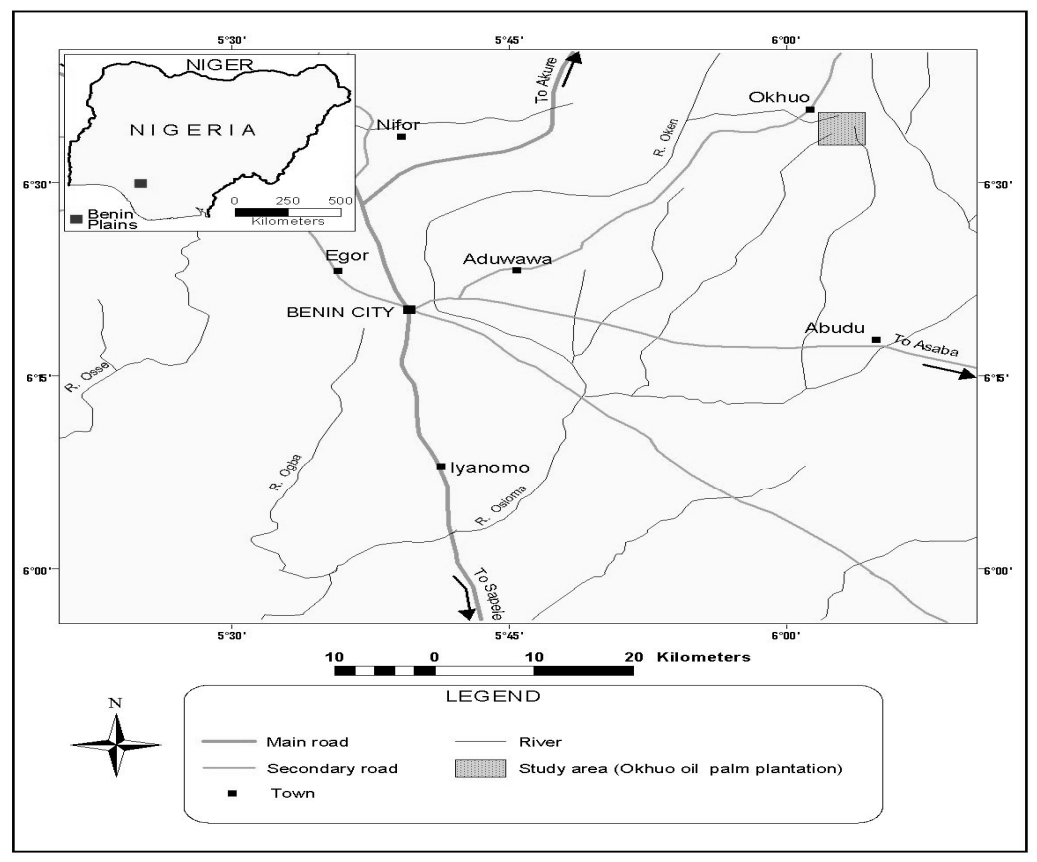

Fig. 1: Map of Benin Plains, S.W. Nigeria, showing the study area

The study of Lal et al has shown that removing the top $7.5 \mathrm{~cm}$ of the soil in south-western Nigeria resulted in $90 \%$ reduction in corn yield ( $\mathrm{Lal}$ et al 1975). Furthermore, it has been shown that the effect of tree vegetation on soil organic matter and nutrients in the forest zone of south-western Nigeria is largely restricted to the top $10 \mathrm{~cm}$ of the soil solum (Aweto 1981). The soil samples were air-dried, passed through a $2 \mathrm{~mm}$ mesh sieve, prior to soil physical and chemical analysis. Soil particle size composition was determined using the hydrometer method ( Bouyoucos 1951) and organic carbon by the method of Walkley \& Black (1934). Kjeldahl method was used for determining total nitrogen while available phosphorus was measured colorimerically after extraction with Bray P-1 solution (Bray \& Kurtz 1945). Soil extracts used for determination of exchangeable bases were obtained by leaching the soil using neutral $1 \mathrm{M}$ ammonium acetate solution. Calcium, potassium and sodium were determined by flame photometry and magnesium was determined using atomic absorption spectrophotometer. Soil $\mathrm{pH}$ was determined potentiometrically in $1 \mathrm{~N} \mathrm{KCL}$ using 1:1 soil to solution ratio. Exchangeable acidity was determined by barium chloride triethanolamine method while cation exchange capacity was determined by the summation method ( Chapman 1965). Extractable micronutrients were leached from the soil using 0.1 M HCL and zinc, iron, copper and manganese in the leachate determined on the atomic absorption spectrophotometer.

Soil physical and chemical properties in the three slope positions were compared using Analysis of variance (ANOVA) to ascertain whether or not there were significant differences in their physical and chemical properties.

Results and Discussion

There were no significant differences between the upper, middle and lower slope segments of the catena in respect of soil particle size composition, although the proportion of clay was higher in the middle slope than in the other two segments of the catena (Table 1). Sand is the dominant inorganic fragment in all three segments of the catena and sand accounts for a mean proportion of $79-83 \%$ of the inorganic soil fragments with the higher value occurring in the lower slope soils of the catena. The study area is a part of the coastal plain of southern Nigeria which is characterized by very sandy soils over wide expanses of land. Soil organic matter content is highest in the middle slope, presumably due to the higher clay content of soils in this slope segment. More clayey soils generally tend to contain higher levels of organic matter mainly because of the tendency of clays to slow down microbial degradation of 
organic matter as clays form clay-humus complexes with organic matter ( Brady \& Weil 1999). There were no significant differences between the three slope segments in respect of total nitrogen, although nitrogen is highest in the middle slope and this reflects the higher organic matter status of the middle slope. Exchangeable calcium and cation exchange capacity were significantly higher in the middle slope, reflecting the higher clay and organic matter status of that slope segment. Exchangeable magnesium was however, highest in the upper slope and declined downslope. There were no significant variations in exchangeable potassium and sodium and in available phosphorus between the three slope segments while soil $\mathrm{pH}$ declined significantly downslope. The decline in soil $\mathrm{pH}$ is partly due to the decline of exchangeable cations, especially magnesium, and base saturation downslope (Table 1). Given the low cation exchange capacity of the soils, they have low buffering capacity. Hence, slight changes in soil base cations or in exchange acidity would result in a change in soil $\mathrm{pH}$.

With the exception of extractable iron whose concentration was significantly higher in the lower slope segment, the levels of the micronutrients manganese, copper and zinc did not vary significantly between the upper, middle and lower slope. Soil moisture is an important factor affecting the extractable iron status of the soil. In many soils in southwestern Nigeria extractable iron content decreased dramatically when wet soil was airdried ( Banjoko \& Ashaye 1981). The higher extractable iron content of the lower slope soil is obviously due to the higher moisture status of the soils in lower topographic location near the river, compared to the drier soils in the upper and middle slope.

In a catena developed in an area of low gentle relief, under swamp forest in the coastal plain of south western Nigeria, Aweto and Iyamah (1993) observed no significant variations in soil physical and chemical properties between the upper, middle and lower slopes. In almond tree plantations in southern Spain, there were also no significant spatial variations in soil properties, except for higher soil moisture content in the low part of the catena ( Van Wesemael et al 2003). In the Chittagong hill of eastern Bangladesh, there were no significant differences between the upper, middle and lower slopes of the catena (Gafar et al 2004). Soil properties are not always uniform in all slope segments of the catena. Several studies have shown that organic matter and soil nutrient levels are higher in the lower slope segment of the topography ( Furley 1974, Enoki et al 1996, Abrams et al 1997, Kravchenko \& Bullock 2000). Soils in lower or river channels receive considerable quantities of sediments and organic debris transported from upslope or upstream which enhance their organic matter and nutrient status. In addition, soils in lower topographic location are not only characterized by lower slope angles, on account of which they hold greater quantity of water than higher slope soil ( Lopez et al 2003), they are also saturated with moisture for a much longer period than upper slope soils. This usually slows down the rate of microbial degradation and mineralization of organic matter in lower slope position. The results obtained by Gao et al (2009) indicate that carbon dioxide evolution is strongly depressed by increased water saturation. This implies that microbial decomposition of organic matter is reduced in wet lower slope position as to be expected. In the current study, soil organic matter and macronutrients were higher in the middle slope than in the lower slope presumably because the higher sand content of the lower slope negated a substantial accumulation of organic matter in it, relative to the levels in the middle slope with higher clay content. Furthermore, the slope angle of the ground appears to be another crucial factor accounting for the lower organic matter and nutrient content of the lower slope segment and hence, spatial variations of soil properties in the catena studied. The lower slope is characterized by steeper slope angle than the middle and the upper slope units. The mean slope angles of the lower, middle and upper slopes are $10.3^{\circ}, \quad 2.3^{\circ}$ and $2.3^{\circ}$ respectively. The implication of the greater slope angle in the lower slope near the river is that runoff velocity would increase downslope. Hence, most of the sediments and organic debris transported from upslope, would be washed into the river instead of being deposited on the lower slope segment.

The soils in all three slope segments of the catena contain low levels of nutrients. This is particularly so in respect of exchangeable potassium and available phosphorus. Exchangeable potassium is below the critical 
limit of $0.15 \mathrm{cmol} \mathrm{kg}^{-1}$ while available phosphorous levels are well below $10 \mathrm{mg} \mathrm{kg}^{-1}$ and this indicates that the soils are deficient in both vital plant nutrients ( Uponi \& Adeoye 2000). The low nutrient content of the soils is due to the fact that they are predominantly sandy and were derived from deeply weathered coastal sediments derived from sandstone which is deficient in weatherable mineral reserves.

There is a slight concavity in the middle slope which would result in trapping of part of the sediments and nutrients transported from upslope into this slope segment. The enhanced organic matter, clay and nutrient levels in the middle part of the catena is therefore, partly attributable to the illuviation of sediments and organic matter washed down from the upper slope.

\section{Conclusion}

The soils derived from sedimentary rocks in southern Nigeria, especially those derived from the same parent material (as in the study area) are supposedly homogenous over large areas on account of which they have been recommended for large scale plantation agriculture ( Moss 1957). The findings of this study, however, indicate that within a limited area of a few hectares, soil properties vary along the catena on the sedimentary soils, even under the same land use. Topographical position and ground slope are the main factors accounting for variations in soil properties in the catena studied. Soil $\mathrm{pH}$, base saturation, cation exchange capacity, exchangeable calcium and magnesium and extractable iron vary significantly between the upper, middle and lower slope positions of the catena. The middle slope, which had higher clay content and is also characterized by more gentle slopes, had higher cation exchange capacity and exchangeable calcium while the lower slope had higher extractable iron on account of the higher moisture content. The implication of the higher nutrient content of the slightly more clayey middle slope soils is that on

\section{References}

Abrams, M.M., Jacobson, P.J., Jacobson, K.M. and Seely, M.K. (1997), Survey of soil chemical properties across a landscape in the Namib Desert. Journal of Arid Environments. 35, 29-38. predominantly sandy soils, such as occurs in the study area, variations in soil textural composition influences soil fertility status and hence plantation productivity. The more clayey sites are characterized by higher organic matter and cation exchange capacity and hence, plantations established on such sites would be more productive and sustainable in the long run. Another implication of catenary variation in soil properties, is that a plantation of the same age and crop occurring on different topographic positions would have to be managed differently. Soil $\mathrm{pH}$ and base saturation declined downslope, implying decreased availability of plant nutrients in the lower slope topographic position. The need for liming to raise soil base saturation and increase nutrient availability and also to ameliorate problems of iron and aluminum toxicity becomes more crucial in the lower slope. Furthermore, sandy soils in upper slope position will be more prone to desiccation and moisture stress during the dry season than comparable soil in lower topographic position where the ground water table is higher. The uptake of nitrogen, phosphorus, potassium and magnesium by oil palms decreases with increasing moisture stress (Ugbah \& Babalola 1991). This implies that those parts of oil palm plantations on more sandy soils or in higher topographic location that are more prone to moisture stress during the dry season, will also experience the additional problem of decreased uptake of vital plant nutrients and an attendant adverse effect on oil palm productivity. This again underscores the need to manage parts of oil palm plantation on different topographic positions differently, taking cognizance of variations in soil properties along the catena.

Finally, it is important to point out that the present study was restricted to the properties of the topsoil layer. Subsequent studies on catenary differentiation of soils under oil palm and other types of plant cover should consider the subsoil layers as well.

Aweto, A.O. (1981), Organic matter build-up in fallow soil in a part of South-western Nigeria and its effects on soil properties. Journal of Biogeography, 8, 67-74. 
Aweto, A.O. and Ekiugbo, U.E. (1994), Effect of an oil palm plantation on a tropical forest soil in south western Nigeria. The Indonesian Journal of Geography, 26, 51-59.

Aweto, A.O. and Iyamah, C.C. (1993), Catenary variation of vegetation in a swamp forest in South-western Nigeria. International Journal of Environmental Studies, 43, 133140.

Banjoko, V.A. Ashaye, T.I. (1981), The effect of moisture regime on the extractable $\mathrm{Fe}$ content of selected soils of southwestern Nigeria. Nigerian Journal of Soil

Science, 1, 18-29.

Bouyoucos, G.J. (1951), A calibration of the hydrometer method for making mechanical analysis of soils. Agronomy Journal, Vol. 43, pp. $434-438$.

Brady, N.C. and Weil, R .R. (1999), The Nature and Properties of Soils, Prentice Hall, Upper Saddle River.

Bray, R.H. and Kurtz, L.T. (1945),

Determination of total, organic and available forms of phosphorus in soils. Soil Science, $\mathbf{5 9}$, $39-48$

Chapman, H.D. (1965), "Cation-exchange capacity”, In: Black, C. A. (Ed.). Methods_of Soil Analysis. American Society of Agronomy, Madison, pp. 891- 901

Enoki, T., Kawaguchi,H. and Iwatsubo, G.(1996), Topographic variations of soil properties and stand structure in a Pinus thunbergii plantation. Ecological Research, 11, 229- 309.

Evans, J.(1992), Plantation forestry in the tropics. Clarendon Press, Oxford . Furley, P.A.(1974), Soil-slope-plant relationships in the northern Maya mountains, Belize, Cenral America. II. The sequence over Phyllites and granites. Journal of

Biogeography, 1, 263-279.

Furley, P.A.and Newey, W.W. (1979), Variations in plant communities with topography over tropical limestone soils. Journal of Biogeography, 6, 1-15.

Gafar, A., Koch, C.B. and Borggaard, O.K (2004), Weathering intensity controlling sustainability of Ultisols under shifting cultivation in the Chittagong hill tracks of Bangladesh. Soil Science, 169, 663 - 674. Gao, J.Q., Ouyang, H., Xu, X.L., Zhou, C.P. and Zhang, F.(2009), Effects of temperature and water saturation on $\mathrm{CO} 2$ production and nitrogen mineralization in alpine wetland soils. Pedosphere , 19, 71-77.
Gerrard, A.J. (1981), Soils and Landforms, Allen \& Unwin, London.

Hartley, C. W.S. (1998), The Oil Palm, Longman, London.

Hopkins, B. (1974), Forest and savanna, Heinemann, Ibadan.

Irvine, F.R. (1969), West African Crops, Oxford University Press, London.

Kravchenko, A.N. and Bullock, D.G.(2000), Correlation of corn and soybean grain yield with topography and soil properties.

Agronomy Journal, 92, 75-83.

Lal, R. Kang, B.T., Moorman, F.R., Juo, A.S.R. and Moomaw, J.C. (1975)," Soil management problems and possible solutions in western Nigeria". In: Bornemisza, E. and Alvarado (Eds.) Soil Management in Tropical America, North Carolina State University, Raleigh, pp. 372- 408.

Lopez, I.F. Lambert, M.G. Mackay, A.D. and Valentine, I. (2003), The influence of topography and pasture management on soil characteristics and herbage accumulation in a hill pasture in the North Island of New Zealand. Plant and Soil, 255, 421-434. Milne, G. (1935), Some suggested units of classification and mapping particularly for East African soils, Soil Research 4, No. 3 Moss, R.P. (1957), Report on the classification of soils found over sedimentary_rocks in Western Nigeria, Ministry of Agriculture and Natural_Resources, Ibadan.

Ogunwale, J.A., Juo, A.S.R. and Moorman, F.R.(1986), Characteristics and classification of the soils of a catena at Iyanomo-Ologbo in South Western Nigeria. Nigerian Agricultural Journal, 21, 1-13.

Onwueme I.C. and Sinha, T.D. (1991), Field Crop Production in Tropical Africa._CTA, Ede.

Smyth, A.J.and Montgomery, R.F. (1962), Soils and Landuse in Central Western_Nigeria, Government Printer, Ibadan.

Soil Survey Staff, (1996),Keys to Soil Taxonomy, United States Department of Agriculture Natural Resources Conservation Service, Washington, D.C.

Udo, R.K. (1970), Geographical Regions of Nigeria. Heinemann, London.

Ugbah, M.M. and Babalola, O. (1991), Influence of soil physical properties on oil palm root growth. Nigeria Agricultural Journal, 25, 1-8. 
Uponi, J.J. and Adeoye, G.O. (2000), "Soil testing, and plant analysis: an overview". In: Akoroda, M.O. (ed.) Agronomy in Nigeria, Department of Agronomy, University of Ibadan, pp. 174-182.

Van Wesemael, B., Cammeraat, E., Mulligan, M. and Burke, S.(2003), The impact of soil properties and topography on drought vulnerability of rainfed cropping systems in southern Spain. Agriculture, Ecosystems and Environment, 94, 1-15.

Vine, H. (1941), A soil catena in the Nigerian cocoa belt. Farm \& Forest 2, 139-141.
Von Uexkul, H.R. and Fairhurst, T. (1991). The Oil Palm: Fertilizer Management for High Yield, International Potash Institute, Berne.

Walkley, A. and Black, I.A. (1934), An examination of the Detjareff method for determining soil organic matter and a proposed modification to the chromic acid titration method. Soil Science, Vol. pp. 2938.

World Rainforest Movement (2001), Nigeria: Palm oil deficit in a traditional palm oil producing country. WRM bulletin No. 47, June 2001

Table 1: Properties of the $0-20 \mathrm{~cm}$ layer of soil in a catena under oil palm plantation

\begin{tabular}{|c|c|c|c|c|c|}
\hline Soil Properties & $\begin{array}{l}\text { Upper } \\
\text { slope }\end{array}$ & $\begin{array}{l}\text { Middle } \\
\text { Slope }\end{array}$ & $\begin{array}{c}\text { Lower } \\
\text { Slope }\end{array}$ & F- value & $\begin{array}{l}\text { Level of } \\
\text { Significance }\end{array}$ \\
\hline Sand $(\%)$ & 82.2 & 79.0 & 82.8 & 1.35 & $0.277 \mathrm{NS}$ \\
\hline Silt (\%) & 5.4 & 6.0 & 5.2 & 1.42 & $0.259 \mathrm{NS}$ \\
\hline Clay $(\%)$ & 12.4 & 15.0 & 12.0 & 1.31 & $0.287 \mathrm{NS}$ \\
\hline Organic carbon $(\%)$ & 0.85 & 1.14 & 0.98 & 2.59 & $0.093 \mathrm{NS}$ \\
\hline Total nitrogen $(\%)$ & 0.18 & 0.24 & 0.20 & 2.96 & $0.069 \mathrm{NS}$ \\
\hline Available phosphorus (mg/kg) & 2.66 & 1.71 & 3.26 & 1.33 & $0.281 \mathrm{NS}$ \\
\hline Calcium (cmol/kg) & 1.19 & 1.80 & 1.19 & 9.01 & $0.001 * *$ \\
\hline Magnesium $(\mathrm{cmol} / \mathrm{kg})$ & 0.04 & 0.02 & 0.02 & 4.97 & $0.015 *$ \\
\hline Sodium $(\mathrm{cmol} / \mathrm{kg})$ & 0.18 & 0.18 & 0.21 & 1.11 & $0.345 \mathrm{NS}$ \\
\hline Potassium $(\mathrm{cmol} / \mathrm{kg})$ & 0.10 & 0.12 & 0.10 & 0.55 & $0.581 \mathrm{NS}$ \\
\hline $\mathrm{CEC}(\mathrm{cmol} / \mathrm{kg})$ & 2.54 & 4.41 & 3.80 & 8.71 & $0.001 * *$ \\
\hline Base saturation (\%) & 62.71 & 50.59 & 41.66 & 4.33 & $0.023 *$ \\
\hline Manganese $(\mathrm{mg} / \mathrm{kg})$ & 20.0 & 30.7 & 33.5 & 2.93 & $0.071 \mathrm{NS}$ \\
\hline Iron $(\mathrm{mg} / \mathrm{kg})$ & 30.5 & 33.2 & 55.9 & 12.05 & $0.00 * *$ \\
\hline Copper (mg/kg) & 0.97 & 1.06 & 0.92 & 2.51 & $0.100 \mathrm{NS}$ \\
\hline Zinc (mg/kg) & 6.38 & 4.85 & 4.07 & 3.13 & $0.060 \mathrm{NS}$ \\
\hline $\mathrm{pH}$ & 4.85 & 4.30 & 4.21 & 29.65 & $0.00 * *$ \\
\hline
\end{tabular}

** $\quad$ Significant at $1 \%$ confidence level

* $\quad$ Significant at 5\% confidence level

NS Not significant at 5\% confidence level. 